\title{
Knowledge about neonatal jaundice among Nepalese mothers
}

\author{
*Sharmila Shrestha ${ }^{1}$, Marcia A Pertini ${ }^{2}$, Sarita Shrestha ${ }^{3}$, Sabita Maharjan ${ }^{4}$
}

Sri Lanka Journal of Child Health, 2019; 48(3): 215-220

\author{
Abstract \\ Introduction: Neonatal Jaundice (NNJ) is an \\ important contributor to the high neonatal \\ morbidity and mortality in Nepal.
}

Objectives: To assess the knowledge among mothers about NNJ.

Method: A descriptive cross-sectional study was carried out among 177 mothers in Sunakothi, Lalitpur, a village in Kathmandu valley, with an interview schedule and convenient sampling technique.

Results: Of the 177 mothers, $57.1 \%$ were in the 26 30 year age group, $98.7 \%$ had at least four antenatal visits, $81.6 \%$ were Hindus, $50.6 \%$ were educated up to class eleven and $42.9 \%$ were housewives. Around 50\% of mothers had a low level of knowledge (score $<50 \%$ ), 28.6\% had moderate level of knowledge (score $50-75 \%$ ) and $22 \%$ had adequate level of knowledge (score $>75 \%$ ) regarding NNJ. Whilst $84 \%$ of mothers believed that the danger sign of NNJ was inability to feed the baby, $11 \%$ of mothers believed that mental retardation and death were complications of NNJ. A few mothers $(12 \%)$ were aware about the cause of NNJ. Around 74\% mothers believed that exposing the baby to sunlight is the home management of NNJ but only $2 \%$ had heard about phototherapy. Whilst knowledge about NNJ had a statistically significant relationship with maternal education, there was no statistically significant relationship with age, occupation or parity.

Conclusions: This study shows that the mothers in Sunakothi, Lalitpur village in Kathmandu valley,

${ }^{1}$ Karnali Academy of Health Sciences, Nepal,
${ }^{2}$ Wuhan University, Hope School of Nursing,
Wuhan, China, ${ }^{3}$ Iwamura College of Health
Science, Bhaktapur, Nepal, ${ }^{4}$ Asian College for
Advance Studies, Satdobato, Lalitpur
*Correspondence: sharmila_shr@hotmail.com
iD orcid.org/0000-0002-3938-1424 (Received on 25 August 2018: Accepted after revision on 27 October 2018)

The authors declare that there are no conflicts of interest

Personal funding was used for the project.

Open Access Article published under the Creative

Commons Attribution CC-BY (CC) (†) License
Nepal had a poor knowledge about the causes, danger signs, complications and treatment of NNJ.

DOI: http://dx.doi.org/10.4038/sljch.v48i3.8755

(Key words: Knowledge, neonatal jaundice, Nepal)

\section{Introduction}

Around 50\% term and $80 \%$ preterm infants develop jaundice 2-4 days after birth ${ }^{1}$. Most of this newborn hyperbilirubinaemia resolves by the first week of life with liver maturation ${ }^{2}$. Hyperbilirubinemia is an important cause of morbidity in the first week of life $^{3}$. However, correct use of phototherapy and blood exchange to control the serum bilirubin level, can prevent complications ${ }^{2}$. Mother's lack of knowledge or the use potentially harmful childrearing practices can retard the growth and development of some infants ${ }^{4,5}$. Mothers require knowledge about baby care, childhood diseases, immunizations, and infant feeding, during the postpartum period ${ }^{6,7}$. In Nepal, a study conducted at Kanti Bal Hospital reported that $94.5 \%$ of the babies with neonatal jaundice (NNJ) were cured and $5.5 \%$ died $^{3}$. A study conducted in Myanmar reported that $\mathrm{NNJ}$ was the chief cause of neonatal morbidity and mortality and was responsible for $46 \%$ of hospital admission of neonates in the country ${ }^{8}$.

In 2015, a cross sectional study was carried out in Islamabad among 200 respondents to assess the knowledge of mothers regarding NNJ. The study showed that $52.5 \%$ mothers had inadequate score while $47.5 \%$ mothers had an adequate knowledge score $^{9}$. A study conducted in Nigeria among 350 mothers found that $34 \%$ of the mothers had knowledge about a complication of NNJ namely brain damage (kernicterus). About 58\% mothers accepted that exposing the babies to sunlight could prevent the condition. This study concluded that knowledge about NNJ was low and utilization of preventive practices were ineffective ${ }^{10}$. Another study conducted in Nigeria showed that about $92.4 \%$ mothers were aware of $\mathrm{NNJ}, 67 \%$ admitted their jaundiced babies to hospital, 19.4\% followed the traditional medication, and $13.2 \%$ mothers neither took their neonates to hospital nor followed any traditional medication. The study revealed that there is a knowledge gap in mothers of babies with $\mathrm{NNJ}^{11}$. A study conducted by Adebami ${ }^{12}$ showed that $217(63.5 \%)$ mothers had appropriate knowledge whilst $215(36.5 \%)$ mothers had no knowledge about NNJ. This study also showed that 
the knowledge of NNJ was better with increased parity, maternal age and maternal social class, and attendance of antenatal care. In 2015, a study conducted in Lucknow, India among 240 mothers to assess the knowledge of mothers with children aged 0-23 months regarding NNJ revealed that the mothers had inadequate knowledge about NNJ. In this study, about $80 \%$ of mothers had heard about NNJ and about $68.7 \%$ mothers thought fever is the danger sign of $\mathrm{NNJ}^{13}$. We are not aware of any study that appraised Nepalese mothers' knowledge and practice about NNJ.

\section{Objectives}

To assess knowledge among Nepalese mothers toward NNJ that may lead to delay in presentation and inappropriate management of severe hyperbilirubinemia.

\section{Method}

A descriptive cross-sectional study was carried out in Sunakothi, Lalitpur, a village in Kathmandu valley. The mothers who had a child less than two years old and both primi and multi parous mothers were included in the study. The mothers who had a sick and unstable child and mothers with twin babies were excluded.

Data was obtained by using a structured questionnaire through the interview method. The questionnaire was developed by the author through an extensive review of the literature and by consulting those with subject expertise. Educational midwives again reviewed the draft questionnaire and then the tool was pretested. The reliability of the questionnaire, done by split-half technique, was 0.78 . The demographic information was collected using a simple self-designed questionnaire, including the age, educational status, occupation, ethnicity etc. There were 15 questions with a single choice, 10 related to knowledge and 5 related to practice with regards to the management of NNJ. Each item was scored as $1=$ correct answer (best one) and $0=$ wrong answer and no answer. The highest possible score was 15 (100\%), and knowledge and practice levels were categorized as low $(<50 \%)$, moderate $(50-75 \%)$, and adequate $(>75 \%)$.

The data obtained was analysed using SPSS version 17. Ethics approval was obtained from the ethics review committee of Asian College for Advance Studies. The purpose of the study was made clear to each respondent and written informed consent was obtained. Participants were informed that they were free to withdraw any time without reason and assured that the data would be kept private and confidential.

\section{Results}

Table 1 represents the demographic characteristic of the respondents.

Table 1

Demographic characteristic of the respondents

\begin{tabular}{|c|c|}
\hline Cotorom & Th o (0) \\
\hline Age group (vears) & Number (\%) \\
\hline$<20$ & $09(05)$ \\
\hline $20-24$ & $32(18)$ \\
\hline $25-30$ & $101(57)$ \\
\hline $31-35$ & $35(29)$ \\
\hline Religion & \\
\hline Hindu & $145(82)$ \\
\hline Muslim & $05(03)$ \\
\hline Buddhist & $18(10)$ \\
\hline Christian & $09(05)$ \\
\hline Occupation & \\
\hline House wife & $76(43)$ \\
\hline Job & $74(42)$ \\
\hline Student & $18(10)$ \\
\hline Agriculture & $09(05)$ \\
\hline Caste & \\
\hline Janajati & $121(69)$ \\
\hline Chhetri & $35(20)$ \\
\hline Brahmin & $14(08)$ \\
\hline Dalit & $07(04)$ \\
\hline Education & \\
\hline Illiterate & $05(07)$ \\
\hline Primary(1-4 Class) & $09(12)$ \\
\hline Secondary (5-10 class) & $24(31)$ \\
\hline $\begin{array}{l}\text { College (above } 10 \\
\text { class) }\end{array}$ & $39(51)$ \\
\hline Antenatal clinic visit & \\
\hline Yes & $175(99)$ \\
\hline No & $02(01)$ \\
\hline Parity & \\
\hline Primiparous & $97(55)$ \\
\hline Multiparous & $80(45)$ \\
\hline
\end{tabular}

Table 2 shows the level of knowledge about NNJ among the respondents.

Table 2

Level of knowledge about neonatal jaundice (NNJ) among respondents $(n=177)$

\begin{tabular}{|l|c|}
\hline Level of knowledge about NNJ & $\boldsymbol{n}(\mathbf{\%})$ \\
\hline Low $(<50 \%)$ & $51(29)$ \\
\hline Moderate $(50-75 \%)$ & $87(49)$ \\
\hline Adequate $(>75 \%)$ & $39(22)$ \\
\hline
\end{tabular}

Table 3 shows the results of the assessment of maternal knowledge regarding NNJ. 
Table 3: Knowledge and practice of participants about neonatal jaundice (n=177)

\begin{tabular}{|c|c|}
\hline \begin{tabular}{ll|} 
Category \\
\end{tabular} & Number (\%) \\
\hline $\begin{array}{l}\text { Definition of neonatal jaundice (NNJ) } \\
\text { Yellowness of the eyes } \\
\text { Redness of the eyes } \\
\text { Infection of the skin }\end{array}$ & $\begin{array}{l}154(87) \\
14(08) \\
09(05)\end{array}$ \\
\hline $\begin{array}{l}\text { Common problem in newborn } \\
\text { Yes } \\
\text { No }\end{array}$ & $\begin{array}{c}172(97) \\
05(03)\end{array}$ \\
\hline $\begin{array}{l}\text { Foods taken by mothers can cause } N N J \\
\text { Yes } \\
\text { No }\end{array}$ & $\begin{array}{c}154(87) \\
23(13)\end{array}$ \\
\hline $\begin{array}{l}\text { NNJ usually appears between } \\
2-3 \text { days after birth } \\
\text { Don't know } \\
\text { 7-8 days after birth } \\
\text { 5-6 days after birth }\end{array}$ & $\begin{array}{l}83(47) \\
46(26) \\
35(20) \\
14(08)\end{array}$ \\
\hline $\begin{array}{l}\text { Causes of NNJ } \\
\text { Don't know } \\
\text { Infection } \\
\text { Blood incompatibility } \\
\text { Prematurity } \\
\end{array}$ & $\begin{array}{l}131(74) \\
21(12) \\
17(10) \\
08(05)\end{array}$ \\
\hline $\begin{array}{l}\text { Part of the body where jaundice is first noticed } \\
\text { Eyes } \\
\text { Face } \\
\text { All over the body } \\
\text { Hands and feet }\end{array}$ & $\begin{array}{l}140(79) \\
14(08) \\
12(07) \\
12(07)\end{array}$ \\
\hline $\begin{array}{l}\text { Treatment of } N N J \\
\text { Herbal medications } \\
\text { Consult the Doctor } \\
\text { Phototherapy } \\
\text { Exchange transfusion }\end{array}$ & $\begin{array}{l}134(76) \\
25(14) \\
16(09) \\
02(01)\end{array}$ \\
\hline $\begin{array}{l}\text { Signs and symptoms seen in baby while baby was having } N N J \\
\text { Refusal of feeds } \\
\text { High-pitched cry } \\
\text { High grade Fever } \\
\text { Don't know }\end{array}$ & $\begin{array}{l}149(84) \\
124(70) \\
81(46) \\
76(43)\end{array}$ \\
\hline $\begin{array}{l}\text { Effects of } N N J \\
\text { Liver damage } \\
\text { Brain damage } \\
\text { Mental retardation } \\
\text { Death }\end{array}$ & $\begin{array}{l}140(79) \\
18(10) \\
16(09) \\
03(02)\end{array}$ \\
\hline $\begin{array}{l}\text { Early management of } N N J \\
\text { Avoid oil massage to the baby. } \\
\text { Exposing to sunlight early in the morning } \\
\text { Taking the baby to hospital } \\
\text { Don't know }\end{array}$ & $\begin{array}{l}168(95) \\
154(87) \\
21(12) \\
05(03)\end{array}$ \\
\hline $\begin{array}{l}\text { NNJ treatment practices } \\
\text { Put baby in the sun } \\
\text { Give herbs } \\
\text { Hospital treatment } \\
\text { Give sugar water } \\
\text { None }\end{array}$ & $\begin{array}{l}131(74) \\
21(12) \\
12(07) \\
09(06) \\
05(03)\end{array}$ \\
\hline $\begin{array}{l}\text { Do you believe in traditional practice about NNJ? } \\
\text { Yes } \\
\text { No } \\
\text { If yes, what did you do? } \\
\quad \text { Exposure to sunlight } \\
\quad \text { Herbal medicine } \\
\quad \text { Restrict oil massage } \\
\quad \text { Nothing }\end{array}$ & $\begin{array}{l}177(100) \\
0(0) \\
154(87) \\
138(78) \\
115(65) \\
71(40)\end{array}$ \\
\hline $\begin{array}{l}\text { Feeding during first } 3 \text { days } \\
\text { Exclusively breastfed } \\
\text { Breast and formula } \\
\text { Breast milk and sugar water }\end{array}$ & $\begin{array}{l}168(95) \\
02(01) \\
07(04)\end{array}$ \\
\hline $\begin{array}{l}\text { Restrictions followed by the mother } \\
\text { Avoiding food containing turmeric } \\
\text { Have only milk and rice } \\
\text { Avoiding meat and meat products } \\
\text { No need of any restriction }\end{array}$ & $\begin{array}{l}53(30) \\
46(26) \\
41(23) \\
37(21) \\
\end{array}$ \\
\hline $\begin{array}{l}\text { Willingness to take baby to hospital } \\
\text { Yes } \\
\text { No }\end{array}$ & $\begin{array}{c}138(78) \\
39(22)\end{array}$ \\
\hline
\end{tabular}


Among the 177 respondents $87 \%$ correctly identified jaundice as yellowish discolouration of the eyes and $97 \%$ knew that jaundice is common in the newborn. Around half of respondents knew that physiological jaundice occurs in 2-3 days in the newborn baby, but over two thirds could not identify any cause of jaundice. Whilst $79 \%$ mothers correctly identified that jaundice was first noticed in eyes, $76 \%$ believed that treatment was mainly by exposing in sunlight and only $1 \%$ respondents knew that the correct form of treatment of NNJ was phototherapy. With regards to recognizing the signs and symptoms in infant affected with NNJ, 84\% mothers answered that the infant refused to feed, $70 \%$ replied about high pitched cry and $46 \%$ answered about high grade fever. About the effect of NNJ, only $10 \%$ respondents were aware about possible brain damage.

Nepal is a predominantly rural country, where newborn care practices in the home are rudimentary, and some of them are harmful ${ }^{14}$. Traditional beliefs and practices in NNJ for the baby were avoiding oil massage, giving herbal medicine and exposing to sunlight and for mothers were to restrict certain food in her diet such as meat and meat products, certain vegetables and food contain turmeric. About the assessment of maternal practices related to $\mathrm{NNJ}, 95 \%$ respondents avoid oil massage to the baby and $87 \%$ practise exposing babies to sunlight in the early morning as early management of NNJ. Almost all the mothers (95\%) exclusively breastfed during the first 3 days after delivery. The traditional practice of giving herbal medicine in NNJ was acceptable to over two-thirds of the respondents. Traditional practice of restricting certain foods in the mother's diet while the baby had jaundice was followed by $21 \%$ respondents. A majority (78\%), of the respondents were willing to obtain treatment for the baby from hospital.

Maternal knowledge about NNJ was significantly associated with education $(\chi 2=13.71, \mathrm{p}=0.04)$, but not with maternal age $(\chi 2=0.24, \mathrm{p}=0.88)$, occupation $\left(\chi^{2}=0.64, \mathrm{p}=0.73\right)$ or parity $\left(\chi^{2}=0.72\right.$, $\mathrm{p}=0.62)$.

\section{Discussion}

Adequate maternal knowledge, early perception, and care seeking behaviour are fundamental components of effective management of $\mathrm{NNJ}^{15}$. In this study, only $22 \%$ of mothers had an adequate level of knowledge about NNJ whereas a study conducted in Egypt showed that $52.3 \%$ of participants had adequate knowledge about $\mathrm{NNJ}^{16}$. The majority (87\%) of respondents knew that NNJ was yellowness of the eyes and $79 \%$ of the mothers correctly indicated the eyes as the part of the body where jaundice is first noticed. This finding supported previous studies ${ }^{10,17,19}$. The knowledge of the causes of NNJ was low as $74 \%$ of the mothers did not know of any cause. This finding was similar to those in Iran and Nigeria ${ }^{10,17,19}$. In this study around half (47\%) of mothers knew that NNJ usually appears between 2 and 7 days after birth. Regarding the knowledge of danger signs, $84 \%$ of respondents knew that refusal of feeds by the newborn was a danger sign. This finding was similar to that in Nigeria ${ }^{10}$. A large proportion of mothers $(79 \%)$ had a low knowledge about the effect of jaundice. In contrast, a study conducted in Malaysia found that $70 \%$ of mothers knew that jaundice could cause death and brain damage ${ }^{20}$. In our study, only $9 \%$ of respondents were aware of phototherapy as a standard treatment for NNJ. A study conducted in Sri Lanka found that $44 \%$ of respondents were aware of phototherapy as a standard treatment for $\mathrm{NNJ}^{21}$. Regarding willingness to take the baby to the hospital if the baby developed $\mathrm{NNJ}, 78 \%$ of respondents were willing. A study conducted by Goodman ${ }^{10}$ shows that $90.4 \%$ of respondents had willingness to take the baby to hospital. Majority of respondents (74\%) in this study would expose their newborns to sunlight as a treatment practice for NNJ. In subSaharan Africa also, exposure of newborn with jaundice to sunlight was a common practice ${ }^{11,22}$. The traditional practice about NNJ in Nepal was to expose the newborn to sunlight $(87 \%)$ and use herbal medicine $(78 \%)$ which was similar to the study in Vietnam ${ }^{23}$. About $30 \%$ mothers avoid food containing turmeric while their baby had jaundice. Maternal education helps mothers cope with new situations while caring for their infants ${ }^{24}$. This study found that maternal education was significantly associated with knowledge of NNJ. This finding supports the previous studies conducted by Amirshaghaghi and Boo ${ }^{18,20}$.

In this study, there were several limitations. This study was conducted in a small community with mothers who have children less than two years old due to time and personnel constraints. Therefore, a replication of the study should be conducted in different communities and different geographic areas with a larger population of postnatal mothers. The small sample size in our study limits our ability to draw conclusions about the level of maternal knowledge on NNJ among mothers in Nepal. The questionnaire was newly-developed for this study so it needs to be used in various studies in different counties, especially in developing countries. Future studies should be conducted with a larger sample size, including different health centres and communities, and long-term follow-up care should be arranged. 


\section{Conclusions}

This study shows that the mothers in Sunakothi, Lalitpur village in Kathmandu valley, Nepal had a poor knowledge about the causes, danger signs, complications and treatment of NNJ.

\section{Acknowledgement}

We thank all the women who volunteered for this research.

\section{References}

1. Woodgate P, Jardine LA. Neonatal jaundice: phototherapy. BMJ Clinical Evidence 2015; 2015.pii0319.

2. Stoll BJ, Kliegman RM. Jaundice and hyperbilirubinaemia in the newborn, Nelson Textbook of Pediatrics.19th edition, 2012, 603-618.

3. Nepal D, Bastola D, Dhakal, AK, Mishra U, Mahaseth C. Neonatal hyperbilirubinaemia and its outcome. Journal of Institute of Medicine 2009; 31(3).

https://doi.org/10.3126/joim.v31i3.2990

4. Senarath U, Fernando DN, Vimpani G, Rodrigo I. Factors associated with maternal knowledge of newborn care among hospitaldelivered mothers in Sri Lanka. Transactions of the Royal Society of Tropical Medicine and Hygiene 2007; 101(8):823-30.

https://doi.org/10.1016/j.trstmh.2007.03.003 PMid: 17477945

5. Newbrander W, Natiq K, Shahim S, Hamid N, Skena NB. Barriers to appropriate care for mothers and infants during the perinatal period in rural Afghanistan: a qualitative assessment. Global Public Health. 2014; 9(sup1): S93-109.

6. Gupta P, Srivastava VK, Kumar V, Jain S, Masood J, Ahmad N, Srivastava JP. Newborn care practices in urban slums of Lucknow city, UP. Indian Journal of Community Medicine 2010; 35(1):82. https://doi.org/10.4103/0970-0218.62570 PMid: 20606927 PMCid: PMC2888375

7. Shrestha S, Adachi K, Petrini MA, Shrestha S. Factors associated with post-natal anxiety among primiparous mothers in Nepal. International Nursing Review 2014; 61(3):427-34.

https://doi.org/10.1111/inr.12118

PMid: 25039801
8. Arnolda G, Nwe HM, Trevisanuto D, Thin

AA, Thein AA, Defechereux T, et

al.Kumara D, Moccia L. Risk factors for acute bilirubin encephalopathy on admission to two Myanmar national paediatric hospitals. Maternal Health, Neonatology and Perinatology 2015; 1(1):22. https://doi.org/10.1186/s40748-015-0024-3 PMid: 27057339 PMCid: PMC4823679

9. Yaqub A, Safdar F, Ghani Z. To assess the knowledge of mothers regarding neonatal jaundice presenting to Rawal Institute of Health Sciences Islamab. Isra Medical Journal. 2016; 8(1):28-31.

10. Goodman OO, Kehinde OA, Odugbemi BA, Femi-Adebayo TT, Odusanya OO. Neonatal jaundice: knowledge, attitude and practices of mothers in Mosan-Okunola community, Lagos, Nigeria. Nigerian Postgraduate Medical Journal 2015; 22(3):158.

https://doi.org/10.4103/1117-1936.170741 PMid: 26739202

11. Onyearugha CN, Chapp-Jumbo A, George IO. Neonatal jaundice: evaluating the knowledge and practice of expectant mothers in Aba, Nigeria. Journal of Health Science Research 2016; 1(2):42-7.

12. Adebami OJ. Appraisal of maternal knowledge of neonatal jaundice in Ilesa, South-western Nigeria: What implications for persistence of acute bilirubin encephalopathy in developing countries. Basic Research Journal of Medicine and Clinical Sciences 2015; 4(6):156-6.

13. Shukla M, Agarwal M. Knowledge of mothers regarding neonatal jaundice attending immunization clinic at a tertiary care hospital of Lucknow. International Journal of Applied Research 2016; 2:297-9. https://doi.org/10.18311/jhsr/2016/v1/i2/491 8

14. Yadav S. Newborn care: traditional practices in Nepal. Available from:

https://www.researchgate.net/publication/31 6366948_Newborn_care_traditional_practic es_in_Nepal

15. Ezeaka CV, Ugwu RO, Mukhtar-Yola M, Ekure EN, Olusanya BO. Pattern and predictors of maternal care-seeking practices for severe neonatal jaundice in Nigeria: a multi-centre survey. BMC Health Services Research 2014; 14(1):192. 
https://doi.org/10.1186/1472-6963-14-192 PMid: 24774506 PMCid: PMC4032169

16. Moawad EM, Abdallah EA, Ali YZ. Perceptions, practices, and traditional beliefs related to neonatal jaundice among Egyptian mothers: A cross-sectional descriptive study. Medicine 2016; 95(36).

https://doi.org/10.1097/MD.0000000000004 804

17. Khalesi N, Rakhshani F. Knowledge, attitude and behaviour of mothers on neonatal jaundice. Journal of the Pakistan Medical Association 2008; 58(12):671.

PMid: 19157319

18. Amirshaghaghi A, Ghabili K, Shoja MM, Kooshavar H. Neonatal jaundice: knowledge and practice of Iranian mothers with icteric newborns. Pakistan Journal of Biological Sciences 2008; 11(6):942-45.

https://doi.org/10.3923/pjbs.2008.942.945

PMid: 18814662

19. Egube BA, Ofili AN, Isara AR, Onakewhor JU. Neonatal jaundice and its management: knowledge, attitude, and practice among expectant mothers attending antenatal clinic at University of Benin Teaching Hospital, Benin City, Nigeria. Nigerian Journal of Clinical Practice 2013; 16(2):188-94. https://doi.org/10.4103/1119-3077.110147 PMid: 23563460

20. Boo NY, Gan CY, Gian YW, Lim KS, Lim MW, Krishna-Kumar H. Malaysian mothers' knowledge \& practices on care of neonatal jaundice. Medical Journal of Malaysia 2011; 66(3):239-43.

PMid: 22111448
21. Rodrigo BK, Cooray G. The knowledge, attitude \& behaviour on neonatal jaundice of postnatal mothers in Provincial General Hospital, Badulla. Sri Lanka Journal of Child Health 2011; 40(4): 164-8.

https://doi.org/10.4038/sljch.v40i4.3842

22. Ogunlesi TA, Abdul AR. Maternal knowledge and care. Seeking behaviors for newborn jaundice in Sagamu, Southwest Nigeria. Nigerian Journal of Clinical Practice 2015; 18(1):33-40.

PMid: 25511341

23. Le LT, Partridge JC, Tran BH, Le VT, Duong TK, Nguyen HT, Newman TB. Care practices and traditional beliefs related to neonatal jaundice in northern Vietnam: a population-based, cross-sectional descriptive study. BMC Pediatrics 2014; 14(1):264.

https://doi.org/10.1186/1471-2431-14-264 PMid: 25316215 PMCid: PMC4287314

24. Shrestha S, Adachi K, Petrini MA, Shrestha S, Khagi BR. Development and evaluation of a newborn care education programme in primiparous mothers in Nepal. Midwifery 2016; 42:21-8.

https://doi.org/10.1016/j.midw.2016.09.006 PMid: 27710817 